\title{
Communication
}

[Comunicação]

\section{A retrospective PCR investigation of avian Orthoreovirus, chicken infectious anemia and fowl Aviadenovirus genomes contamination in commercial poultry vaccines in Brazil}

\author{
[Estudo retrospectivo de vacinas avícolas vivas por PCR para os vírus da anemia das galinhas, \\ Aviadenovirus aviário e Orthoreovirus aviário]

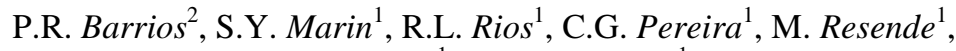 \\ J.S. Resende ${ }^{1}$, N.R.S. Martins ${ }^{1} *$ \\ ${ }^{1}$ Escola de Veterinária - Universidade Federal de Minas Gerais, Belo Horizonte, MG \\ ${ }^{2}$ Universidade Federal de Lavras - Lavras, MG
}

Commercial vaccines have been a major tool for inducing flock protection on the prevention of important infectious diseases of chickens. However, live vaccines may represent a risk, especially considering purity, by the presence of otherwise unknown infectious agents, therefore not searched for. Monitoring SPF flocks, source of eggs and tissues, based on low sensitivity methods, may have also contributed to risk. Fowl Aviadenovirus (FAdV), avian Orthoreovirus (ARV) and chicken anemia virus Gyrovirus (CAV) are major pathogens which had been present sub-clinically in specific pathogen free (SPF) flocks of chickens (Yuasa et al., 1979; Cardona et al., 2000; Miller et al., 2001) and may be horizontally transmitted, on failed biosecurity, and vertically to the embryos (Schat, 2003). CAV was previously described in industrial (Brentano et al., 1991) and free-range chickens (Barrios et al., 2009) in Brazil. SPF flocks are used in research and for the production of vaccines, and their infection may represent a most relevant epidemiological risk, especially concerning lack of purity of live vaccines, therefore requiring highly sensitive and specific monitoring assays.

A retrospective study was conducted with 26 freeze-dried live virus and two inactivated vaccines commercially available for poultry in Brazil, produced from 1991 to 2005, aiming to investigate the contamination with ARV, CAV and FAdV as extraneous genomes. Vaccines were available originally sealed and stored at refrigeration $\left(4-8^{\circ} \mathrm{C}\right)$. Reference DNA for CAV was obtained from a vaccine strain (AviPro Thymovac ${ }^{\circ}$, Lohmann Animal Health, Germany), for Aviadenovirus from FAdV Phelps, kindly provided by Dr. Jane K. A. Cook, and RNA for ARV from the S1133 vaccine strain (Poulvac Reo, Fort Dodge). DNA extractions were performed using silica (Silicon dioxide, Sigma-Aldrich, USA) adsorption protocol previously described (Boom et al., 1999), removing protein with sodium iodide (Caxito et al., 2006). Silica adsorbed DNA was eluted by adding $50 \mu \mathrm{l}$ TE $(5 \mathrm{mM}$ Tris- $\mathrm{HCl} \mathrm{pH} 8.0,0.5 \mathrm{mM}$ EDTA pH 8.0) and stored at $-20^{\circ} \mathrm{C}$ until tested. RNA extraction (Trizol ${ }^{\circledR}$, Invitrogen, USA) was based on a protocol designed for infectious bursal disease virus (IBDV) (Gomes et al., 2005). All DNA and RNA extracts concentrations were estimated (NanoDrop ND1000) for assay. The quantified RNA was immediately transcribed (300ๆg) into ARV cDNA using reverse transcriptase (M-MLV, Promega, USA) according to the manufacturer instructions and using the external forward primer. As negative controls, the mixture of all reagents except for the DNA template were used. Total DNA was employed as template for CAV or FAdV PCR, or cDNA for ARV RT-PCR, using primers and protocols as previously described (Table 1) in a thermocycler (Maxygene, Axygen, USA). PCR products were resolved in agarose (1\%) gel electrophoresis

Recebido em 14 de março de 2011

Aceito em 13 de setembro 2011

*Autor para correspondência (corresponding author)

E-mail: nrsmart@gmail.com 
(TBE 0.5X - 100mM Tris-base $\mathrm{pH} 8.3,25 \mathrm{mM}$ EDTA and $50 \mathrm{mM}$ boric acid) and expected molecular sizes (Table 1) visualized at UV transiluminator (Hoefer Scientific Instruments, USA).

Results indicated that vaccines from three different manufacturers (A, B and C) presented the contaminating genomes (Table 2). Out of the 26 live vaccines tested, five (19\%) presented the expected CAV products, with molecular sizes of 388 and $211 \mathrm{bp}$, for the first and nested reactions, respectively. Nine $(34.6 \%)$ vaccines presented the expected (738 and 342bp) amplicons for $A R V$, for the first and nested reactions, respectively. Three $(11 \%)$ vaccines showed the expected $897 \mathrm{bp}$ amplicon for FAdV. The Newcastle disease (La Sota strain) vaccine, produced in Jan/1991 and May/1992, and the avian encephalomyelitis (Van Roekel strain) vaccine, produced in Jan/1994, were all from manufacturer $\mathrm{A}$ and contained the three specific amplicons (CAV, ARV and FAdV) contaminations. Two Marek's disease HVT lyophilized vaccines, from two different manufacturers (B and C), produced in February and July/1996, presented both CAV and ARV genome contaminations. One Newcastle disease (Jan/1998), one infectious bursal disease (NovDec/1998) and two infectious bronchitis (SeptDec/1998) vaccines, all from the same manufacturer (B), presented ARV contamination.

More recently manufactured vaccines, produced in 2001 and onwards, were tested negative for genomes of the three viruses.

It was refreshing to know that vaccines produced from 2001 and onwards were free from the contaminating genomes, indicating improved quality of the specific pathogen free (SPF) flocks. Vaccines of manufacturers D, E, F, G and $\mathrm{H}$ have never shown contamination. Although not considered for discussion, due to the small sample, two commercial inactivated oil-emulsion vaccines were tested negative for all genomes here studied.

Table 1. Primers and amplicons for Aviadenovirus, avian Orthoreovirus and chicken infectious anemia virus

\begin{tabular}{|c|c|c|}
\hline PCR & Primer & Product (bp) \\
\hline \multirow{2}{*}{$\begin{array}{l}\text { Aviadenovirus } \\
\text { Meulemans et al. } \\
\text { (2001). }\end{array}$} & F: 5'-(CAA GTT CAG GCA GAC GGT)-3' & \\
\hline & R: 5'- (TAG TGA TGC CGC GAC ATC AT)-3' & 897 \\
\hline \multirow{5}{*}{$\begin{array}{l}\text { Avian } \\
\text { Orthoreovirus } \\
\text { Liu et al. }(1997)\end{array}$} & Transcription & \\
\hline & 5'-(ATT GAA TTC TCT GTT ATC TCA ACC TTG)-3' & \\
\hline & $\begin{array}{l}\text { External S1C 5-(ATT GAA TTC TCT GTT ATC TCA ACC } \\
\text { TTG)-3, }\end{array}$ & \\
\hline & $\begin{array}{l}\text { External S1D 5'-(AAG GAA TTC GTT GAG AAC AGA AGT } \\
\text { AGG)-3' } \\
\text { Internal S1E 5-(TCT GAA TTC ATC GCA GCG AAG AGA } \\
\text { GGT CG)-3' }\end{array}$ & 738 \\
\hline & $\begin{array}{l}\text { Internal S1F 5'-(AGT GAA TTC AGT ATC GCC GCG TGC } \\
\text { GCA G)-3' }\end{array}$ & 342 \\
\hline \multirow{3}{*}{$\begin{array}{l}\text { Chicken infectious } \\
\text { anemia virus } \\
\text { Cardona et al. } \\
(2000) \text {. }\end{array}$} & External O3F: 5'-(CAA GTA ATT TCA AAT GAA CG)-3' & \\
\hline & $\begin{array}{l}\text { External O3R: 3'-(TTG CCA TCT TAC AGT CTT AT) } \\
\text { Internal N3. 5'-(CCA CCC GGA CCA TCA AC)-3' }\end{array}$ & 388 \\
\hline & Internal N4: 3'-(GGT CCT CAA GTC CGG CAC ATT C) & 211 \\
\hline
\end{tabular}


Table 2. PCR investigation of ARV, CAV and FAdV in commercial poultry vaccines

\begin{tabular}{|c|c|c|c|c|c|}
\hline Month/Year ${ }^{1}$ & Vaccine $^{2}$ & Manufacturer $^{3}$ & $\mathrm{ARV}^{4}$ & $\mathrm{CAV}^{5}$ & FAdV $^{6}$ \\
\hline 1. Jan/1991 & Newcastle disease & A & + & + & + \\
\hline 2. Dec/1991 & Infectious bronchitis & $\mathrm{C}$ & - & - & - \\
\hline 3. May/1992 & Newcastle diasease & A & + & + & + \\
\hline 4. Dec/1992 & Infectious bronchitis & B & - & - & - \\
\hline 5. Jan/1994 & Avian encephalomyelitis & A & + & + & + \\
\hline 6. Jan/1995 & Fowl pox & E & ND & $\mathrm{ND}^{7}$ & - \\
\hline 7. Jan/1995 & Infectious bronchitis & $\mathrm{H}$ & ND & - & ND \\
\hline 8. Feb/1996 & Marek's disease & B & + & + & - \\
\hline 9. Jul/1996 & Marek's disease & $\mathrm{C}$ & + & + & - \\
\hline 10. Sep/1997 & Infectious bronchitis & B & - & - & - \\
\hline 11. Jan/1998 & Newcastle disease & B & + & ND & ND \\
\hline 12. Sep/1998 & Infectious bronchitis & B & + & - & - \\
\hline 13. Nov/1998 & Infectious bursal disease & B & - & - & - \\
\hline 14. Dec/1998 & Infectious bursal disease & B & + & - & - \\
\hline 15. Dec/1998 & Infectious bronchitis & B & + & - & - \\
\hline 16. Sep/2001 & Infectious bronchitis & $\mathrm{F}$ & - & - & - \\
\hline 17. Feb/2002 & Infectious bronchitis & $\mathrm{D}$ & - & - & - \\
\hline 18. May/2004 & Egg drop syndrome ${ }^{8}$ & $\mathrm{C}$ & - & - & - \\
\hline 19. Jul/2004 & Infectious bursal disease & $\mathrm{C}$ & - & - & - \\
\hline 20. Jul/2004 & Newcastle disease & $\mathrm{C}$ & ND & - & - \\
\hline 21. Aug/2004 & Infectious bronchitis & $\mathrm{C}$ & - & - & - \\
\hline 22. Nov/2004 & Newcastle disease & $\mathrm{D}$ & - & - & - \\
\hline 23. Mar/2005 & Infectious bronchitis & $\mathrm{D}$ & - & - & - \\
\hline 24. May/2005 & Avian encephalomyelitis & $\mathrm{C}$ & - & - & - \\
\hline 25. Jun/2005 & Newcastle disease & E & - & - & - \\
\hline 26. Aug/2005 & Newcastle disease & D & - & - & - \\
\hline 27. Aug/2005 & $\begin{array}{l}\text { Fowl pox and Avian } \\
\text { encephalomyelitis }\end{array}$ & G & - & - & - \\
\hline 28. Sep/2005 & $\begin{array}{l}\text { Infectious bronchitis/Infectious } \\
\text { Coryza/Egg drop syndrome }\end{array}$ & D & - & - & - \\
\hline
\end{tabular}

Notes: 1. Date of manufacturing; 2. Live lyophilized; 3. Major manufacturers in Brazil; 4. ARV: Avian Orthoreovirus; 5. CAV: Chicken anemia vírus Gyrovirus; 6. FAdV: Fowl Aviadenovirus; 7. ND: not done; 8. Inactivated vaccine; +: Positive for specific amplicon; -: Negative for specific amplicon.

It is hypothesized that the detection of contaminating virus genomes (ARV, CAV and FAdV) may indicate a risk for extraneous viral activity in such vaccines, especially taking into consideration the highly resistant nature of the evaluated viruses and the type of vaccine (live), formulated to preserve virus infectivity, for inducing infection and immunity.

It is of obviously ultimate importance the purity and innocuity of live vaccines, quality dependent on the health status of SPF flocks and eggs. However, a few methods employed for monitoring the investigated infections in SPF flocks may be of low sensitivity, as the agar gel immunodiffusion for FAdV (Fadly et al., 1980; Mockett and Cook, 1983), presently at use for such flocks. Also, monitoring CAV infection based on antibody detection may present false negative results for low virus excreting flocks (Miller et al., 2001). ARV tests for SPF flocks are also based on antibody detection. However, vaccine contamination may principally occur due to SPF flock breakdowns, due to inadequate biosecurity standards or a recent infection prior to egg collection, than to insufficient sampling and testing of the flock or inadequate sensitivity of used tests. The mass administration of a contaminated live vaccine could enable rapid national spread of an infectious agent, of difficult subsequent eradication (Contingency, 2006). PCR methodology enables highly specific and sensitive detection of genomes of live and inactivated agents. Such advances are becoming 
available and being recommended for the rapid and specific diagnosis of relevant viruses, bacteria and other infectious agents of disease (World, 2008). In view of the risk and in order to ensuring rapidity, high sensitivity and high specificity for monitoring SPF flocks, the use of molecular methods may be valuable.

Keywords: Chicken, vaccine, avian Orthoreovirus, Aviadenovirus, Gyrovirus

\section{RESUMO}

Vacinas avícolas vivas comerciais produzidas entre 1991 e 2005 foram examinadas para a presença de genomas dos vírus da anemia infecciosa das galinhas (Gyrovirus CAV), da hepatite por corpúsculo de inclusão (Aviadenovirus FAdV) e da artrite viral/síndrome da má absorção (Orthoreovirus aviário ARV). Vinte e seis partidas de vacinas vivas liofilizadas de oito fabricantes com lacre original foram examinadas. As extrações de DNA e PCR de CAV e FAdV, e de RNA e RT-PCR para ARV, foram descritas previamente. Contaminações triplas de ARV, CAV e FAdV foram detectadas em vacinas de mesmo fabricante, produzidas em 1991 e 1992 contra a doença de Newcastle (DN), e para a encefalomielite aviária, produzida em 1994. ARV e CAV em co-infecção foram encontrados em vacinas contra a doença de Marek liofilizadas produzidas em 1996 por dois fabricantes diferentes. Genoma de $A R V$ foi detectado em vacinas contra a bronquite infecciosa de setembro e dezembro de 1998, doença infecciosa bursal, de dezembro de 1998 e DN de janeiro de 1998. Três dos oito fabricantes apresentaram vacinas com contaminação e cinco nunca apresentaram vacinas contaminadas. Nenhuma vacina produzida a partir de 2001 apresentou contaminação. Cogita-se um papel epidemiológico para vacinas vivas, como fonte de infecção para ARV, CAV e FAdV e, potencialmente determinante da atual alta disseminação destes.

Palavras-chave: galinha, vacina, Aviadenovirus, Gyrovirus, Orthoreovirus

\section{AKNOWLEDGEMENTS}

The authors are indebted to FAPEMIG Grant APQ 00342-09 and CNPq Grant 302688/2010-2 for funding. This study was conducted as part of the INCT-IGSPB (Instituto Nacional em Ciência e Tecnologia-Informação Genético-Sanitária da Pecuária Brasileira).

\section{REFERENCES}

BARRIOS, P.R.; MARIN, S.Y.; RESENDE, M. et al. Occurrence of chicken anemia virus in backyard chickens of the metropolitan region of Belo Horizonte, Minas Gerais. Braz. J. Poultry Sci., v.11, 135-138, 2009.

BOOM, R.; SOL, C.; BELD, M. et al. Improved silica-guanidiniumthiocyanate DNA isolation procedure based on selective binding of bovine alpha-casein to silica particles. J. Clinical Microbiol., v.37, p.615-619, 1999.

BRENTANO, L.; MORES, N.; WENTZ, I. et al. Isolation and identification of chicken infectious anemia virus in Brazil. Avian Dis., v.35, p.793800, 1991.
CARDONA, C.J.; OSWALD, W.B.; SCHAT, K.A. Distribution of chicken anemia virus in the reproductive tissues of specific pathogen-free chickens. J. Gen. Virol., v.81, p.2067-2075, 2000.

CAXITO, F. A.; COELHO, F. M.; OLIVEIRA, M.E. et al. Feline immunodeficiency virus subtype b in domestic cats in Minas Gerais, Brazil. Vet. Res. Comm., v.30, p.953-956, 2006.

CONTINGENCY Import Policy For Specific Pathogen Free (SPF) Chicken Eggs. Department Of Agriculture, Fisheries And Forestry. Australian Government, 2006. Available in: http://www.daff.gov.au/_data/assets/pdf_file/00 13/10624/2006-02a.pdf. Accessed on 08 Feb 2012.

FADLY, A.M.; RIEGLE, B.J.; NAZERIAN, K. et al. Some observations on an adenovirus isolated from specific pathogen-free chickens. Poult. Sci., v.59, p.21-27, 1980.

GOMES, A.D.; ABREU, J.T.; REDONDO, R.A.F. et al. Genotyping of infectious bursal disease virus strains by restriction fragment length polymorphism analysis of the VP1, VP2, and VP3 genes. Avian Dis., v.49, p.500-506, 2005. 
MEULEMANS, G.; BOSCHMANS, M.; BERG, T.P. et al. Polymerase chain reaction combined with restriction enzyme analysis for detection and differentiation of fowl adenovirus. Avian Pathol., v.30, p.655-660, 2001.

MILLER, M.; OSWALD, W.B.; SCARLET, J. et al. Patterns of chicken infectious anemia virus (CIAV) seroconversion in three Cornell SPF flocks. In: Int. Symp. Infect. Bursal Dis. Chick Infect. Anaemia, Rauischholzhausen, Germany. Proceedings... Germany, p. 410-417, 2001.

MOCKETT, A.P.A.; COOK, J.K.A. The use of an enzyme-linked immunosorbent assay to detect IgG antibodies to serotype-specific and groupspecific antigens of four adenovirus serotypes 2, 3 and 4. J. Virol. Meth., 7, pp. 327-335, 1983.
SCHAT, K.A. Infectious anemia. In: SAIF, Y.M.; BARNES, H.J.; FADLY, A.M. et al. Diseases of Poultry. Iowa State University, Ames, p.182-202, 2003.

WORLD Organization for Animal Health, Manual of Diagnostic Tests and Vaccines for Terrestrial Animals. Chapter 1.1.9. Tests for sterility and freedom from contamination of biological materials, 2008. Available in: http://www.oie.int/international-standard-setting/ terrestrial-code/access-online/. Accessed on 15 Jul 2011.

YUASA, N.; TANIGUCHI, T.; YOSHIDA, I. Isolation and some characteristics of an agent inducing anemia in chicks. Avian Dis., v.23, p.366-385, 1979. 